EPRA International Journal of Economic and Business Review-Peer Reviewed Journal Volume - 9, Issue - 4, April 2021 | e-ISSN: 2347 - 9671| p- ISSN: 2349 - 0187

\title{
THE EFFECTS OF INTEREST RATE ON STOCK MARKET; EMPIRICAL EVIDENCE FROM THE GHANA STOCK EXCHANGE
}

\begin{tabular}{|c|c|}
\hline Agyemang Kwasi Sampene ${ }^{\mathrm{I}}$ & $\begin{array}{c}\text { 'School of Management, Jiangsu University, } \\
\text { Zhenjiang 212013, P.R. China }\end{array}$ \\
\hline Cai $\mathbf{L i}^{2}$ & $\begin{array}{l}{ }^{2} \text { School of Management, Jiangsu University, } \\
\text { Zhenjiang 212013, P.R. China }\end{array}$ \\
\hline Hairong Cui $^{3}$ & $\begin{array}{l}\text { 3chool of Business, Nanjing University of } \\
\text { Information Science \& Technology, Nanjing, } \\
\text { Jiangsu, China, } 210044\end{array}$ \\
\hline Abredu Pearl ${ }^{4}$ & $\begin{array}{c}{ }^{4} \text { School of Management, Jiangsu University, } \\
\text { Zhenïiang 212013, P.R. China }\end{array}$ \\
\hline Oteng Agyeman Fredrick ${ }^{5}$ & $\begin{array}{c}{ }^{5} \text { School of Management, Jiangsu University, } \\
\text { Zhenjiang 212013, P.R. China }\end{array}$ \\
\hline Brenya Robert $^{6}$ & $\begin{array}{c}{ }^{6} \text { Agriculture Economics and Management, Nanjing } \\
\text { Agriculture University, China. }\end{array}$ \\
\hline Abraham Lincoln Ayisi ${ }^{7}$ & $\begin{array}{l}\text { School of Finance and Economics Zhenjiang, } \\
\text { Jiangsu, 212013, China }\end{array}$ \\
\hline
\end{tabular}

*Corresponding author: Agyemang Kwasi Sampene
ABSTRACT
DOI No: $10.36713 /$ epra6790
Article DOI URL: https://doi.org/10.36713/epra6790

This paper examines the impact of interest rates on the Ghana Stock Exchange performance over 20 years, from 2000 to 2019. Ghana Stock Exchange Composite index was the dependent variable for the study with controlled variables of Interest rate, rate of Inflation, Exchange rate and Money Supply were analyzed in this study. The Johansen Multivariate Cointegration Method was conducted to test if there is a long-term relationship between the interest rate and the Ghana Stock Exchange Composite Index. According to the findings, with a coefficient of $14.63 \%$, interest rates significantly impact the Ghana stock composite index. The inference is that a 1\% increase in interest rates would result in a $14.63 \%$ drop in Ghana Stock Exchange Composite Index. Results of the study also indicated a long-run cointegration among interest rate and the Ghana stock composite index was a significant level of 5\% with a p-value of 0.0025. According to the analysis, policymakers will benefit from this study because it will give them insight into developing and implementing effective fiscal and monetary policies to bolster the financial market.

KEYWORDS: Consumer Price Index, Exchange Rate, Unit Root Test, Johansen Co-integration Test 


\subsection{INTRODUCTION \\ 1.1 Background of the Study}

Stock markets play an essential role in a country's growing industries and trade, impacting the economy. Before investing money in the stock market, investors closely monitor the performance of the composite market index. The stock market index offers historical data on stock market performance; this yardstick helps investors compare individual investors' performance and predict potential market patterns.

Investing in the stock market can be more profitable, but it can also be perilous. This is because many factors need to be considered before an investment decision can be made. One of these considerations is to recognize macroeconomic variables that affect stock market output, such as inflation rate, Gross Domestic Product (GDP), and exchange rate. The stock market helps financial market participants diversify their portfolios, reducing risk while increasing capital or income [1]. Because it is a return rate on investment with a guaranteed or nearly guaranteed payoff, the interest rate in the form of a risk-free rate is critical in investment practice. As a result, investors use T-bills as a point of reference for risk-free rates when making stock market investment decisions. Public traded companies can obtain long-term financing by issuing additional shares or taking out a commercial bank loan. On the other hand, companies frequently seek to reduce capital costs while increasing existing shareholders' wealth. According to the findings [2], lower lending rates are more likely to increase stock markets. As a result, lower interest rates could encourage or motivate businesses to take out more bank loans and issue fewer new shares, lowering their capital cost while reducing the risk of diluting existing stockholders.
The Ghana Stock Exchange is an evolving stock market with many potential future investors; therefore, it has become essential to perform various GSE research to make crucial decisions. Investors expect corporate cash flow to grow in lockstep with the market so that this research may be useful to private investors, policymakers, and the Government. Over the last decade, Ghana's financial sector has seen significant growth or change. The Ghana Stock Exchange (GSE) was established in the late 1980s to encourage domestic resource mobilization and private sector participation in the Ghanaian economy. The Ghana Stock exchange started its operation in 1990 to enable firms to raise funding for the productive venture. The Ghana Stock Exchange (GSE) has performed very well since its inception.

Since it was incorporated, Ghana's Stock Exchange performance has been varied, recording both periods of up and downs. The positive performance but outweighs the negative performance. The market witnessed negative returns for six years. In 2009 the securities market recorded a negative return of $46.58 \%$, which was the worst performance recorded so far. On the other side, the GSE witnessed competitive returns year-on-year, with the positives averaging around $48.89 \%$. The recent surge in returns on the market was recorded in 2013 when the average returns on the market recorded $78.81 \%$ outstripping returns on the fixed income market. In 2003, the market returns were $154.67 \%$, the highest in the history of the exchange. As shown in Figure 1, the Ghana Stock Exchange Composite Index shows instability through the study period. It was reached its peak in 2003, and then in 2009, there was a sharp decline. Between the years 2010 to 2019 , it became a bit stable compared to previous years.

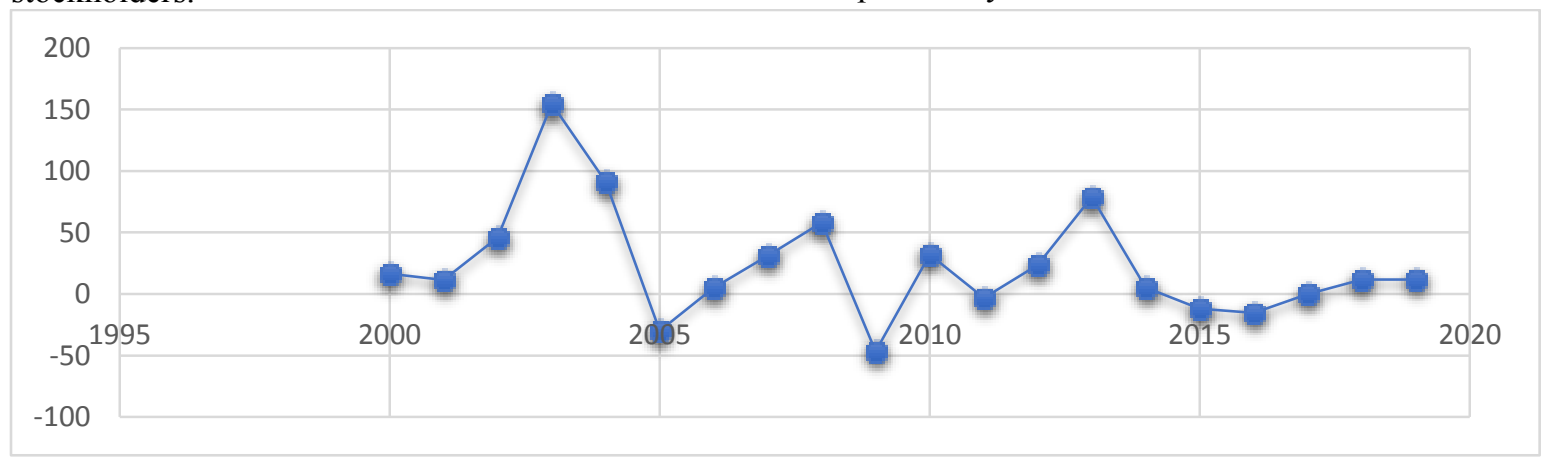

Source: Ghana Stock Exchange

Figure 1: GSE All-Share Index 2000 To 2019

\subsection{Statement of the Problem}

This study aims to see how interest rates affect Ghana's stock market index. The securities market index will show the general health of the economy. Various factors affect the output of stock market indices, including political, social, monetary, and interest rate factors, to name a few. The interest rate was the main subject of this article. This is because; Ghana is an import-oriented country. A slight change in interest rates would have a significant impact on foreign investors' interest in stock trading. Interest rates are expected to have an influence on stock market indices; an effective interest rate strategy should therefore be put in place to encourage international 
investments to invest in stocks. The results of this study will assist policy makers to make informed decisions when investing in stock markets. Various researchers have argued that the robustness or economic success is related to its stock market performance.

Moreover, in order to measure the performance of each country's economy, it is necessary to focus on the macroeconomic aggregates. As a result, the correlation between economic determinants and the results of the stock market needs to be investigated. This has necessitated an analysis of this nature to understand the relationship among interest rates and the performance of Ghana's financial markets.

\subsection{Objectives of the Study}

In 2017, Ghana's Government embarked on a financial sector cleanup, affecting many banks and depositors. Many researchers have been conducted various research work in developed and emerging stock markets, but little and conflicting literature exists when it comes to underdeveloped economies like Ghana. This has created a space in literature, which has necessitated this study. In developed economies, policymakers stimulate their economy by reducing interest rate examples of such countries, including The United Kingdom, France, and China. For an importoriented country like Ghana, a lower interest rate will help boost the economy.

Essentially, studies on the relationship among interest rates and the stock market index will assist in two directions: policy formulation and development of existing literature on the subject. Policymakers may understand the interest rate and stock market development dynamics and will inform the portfolio choice or diversification by investors in the period of lower (higher) interest rates. To spice up the capital market expansion, the Government might pursue acceptable interest policies that may redirect funds to the capital market. Understanding the interest rate's behavior towards the stock market will help local investors attract foreign investors to invest in the Ghanaian stock market. This research will assist policymakers in planning and forecasting policy initiatives that will aid in attracting investors. This is because a successful strategy assumes that corporate cash flow will rise in synch with the economy, so the Government and many long-term investors invest in inequities.

\section{LITERATURE REVIEW}

The theoretical framework, empirical framework, and relationship between macroeconomic variables, relationship among interest rates and the performance of Ghana's financial markets., and comments on the literature reviewed are all included in this section.

\subsection{Theoretical Framework 2.1.1. Classical Theory of Interest}

The Classical Theory of Interest, which was propounded by Marshall and Fisher in the 19th century and later modified by Pigou, Taussing, and others, argued that equality of savings and investment is brought about by interest rate. When savings exceed investment, the interest rate falls and discourages savings but encourages classical economists to invest. Similarly, when investment exceeds savings, the interest rate rises and discourages investment, but this encourages savings. Therefore, interest rate and investment are inversely related, while interest rate and savings have a direct relationship. They, therefore, conclude that savings and investment are corrected by changes in interest rate when income is fully employed.

\subsubsection{Keynesian Savings Investment Equality}

Another theory that supports this study is the Keynesian Savings Investment Equality. Keynes (1935) criticized the classical theory of interest for its unrealistic assumptions of indeterminate, fixed income, full employment, and long-run nature. He opined that equality of savings and investment is not brought about by interest rate changes as claimed by the classical economists but because of changes in income. Savings, according to Keynes (1935), is the excess of income over consumption; investment, on the other hand, is the expenditure other than consumption, and therefore, Savings (S) = Investment (I). When investment exceeds savings, an increased investment must increase an economy's total income to a level that the increased savings out of the increased income are equal to increased investment (Keynes, 1935). It worth noting that both the Classical Theory of Interest and Keynesian Savings Investment Equality agree that equality exists between savings and investment. The scholars of these theories differ only in terms of their explanations.

\subsection{Empirical Studies on Stock Market Indexes and Macro-economic Variables}

Empirically, some researchers focused on one economic indicator, while others concentrate on more than one macroeconomic variable to establish the relation between macroeconomic indicator(s) and volatility of the stock market indices. In this paper, [3] looked into the impact of microeconomic indicators on the Nigerian financial trade, concentrating on deposit earned funds. The study discovered that debt-equity and dividend per share significantly affect Nigeria's stock market results using annual data from 2012 to 2017 and a multiple regression methodology. From [4] From 2012 to 2016, Malaysia investigated various macro and micro variables for firm results. According 
to the findings of the studies, the currency has a negative but substantial effect on the performance of the company. Moreover, both interest rates and financial constraints also have a significant adverse impact on the financial of the company.

[5]The Fisher effect on the Romanian capital market also tested the Romanian capital market's strength by using regression analysis on the monthly data of consumer price index and four selected Bucharest Stock Exchange indices for 15 years. His findings suggested that inflation was not a vital factor in the composite index and the energy index's stock return. However, inflation substantially influenced price fluctuations of shares listed on the Romanian Stock Market (BET) and the investment funds index). [6] A South Africa report concluded that stock indices in the country are unaffected by shifts in inflationary rates. They concluded that the temporary changes in the stock indexes as an outcome of the inflation variations are corrected in the long term, and therefore, inflationary rate and share prices are positively related in South Africa. These findings became known when the researchers examined the interaction of inflationary rate and prices of shares quoted on the South African capital market. The bivariate vector autoregressive was employed to analyze the quarterly data from 1980 to 2010 rigorously.

From 2000 to 2009 , [7] analyzed the interaction of macroeconomic factors and selected stocks from developed and emerging capital markets using monthly time series data. They employed the Vector Error Correction Model in analyzing this data. They found out that countries such as China, the United States (USA), and Malaysia's stock market index and inflation move in the same direction. That is to say, if inflation goes up, all being equal, the indexes of such stock increases. Using data from 1999 to 2009, [8] discovered that India and China's financial market output significantly affected macroeconomic indicators. Using VECM and Multivariate Cointegration techniques, this study identified a long-term inverse association between financial market indexes and money supply.

\subsection{Establishing the relationship among Interest Rate and Stock Market}

[9] looked into the correlation among six countries' stock markets (Germany, Italy, Spain, France, the UK, and the USA) and microeconomic variables like GDP, CPI, IPI, and unemployment. GDP and UMEMP have a statistically significant association with international markets, according to the report.[10] the analysis discovered the presence of market efficiency on the Dhaka Stock Exchange (DSE). The findings of the study of [11] It argued that using Auto Regression Distribution Lag (ARDL), interest rates, currency exchange, copper and oil also have long-term and short-term effect on the Lusaka Securities Market. A study conducted by [12] using a multivariate analysis indicated an inverse relationship between the interest rate and the stock market index. Nevertheless, his research did not reveal whether there is a long-term or short-term correlation between economic growth and the performance of the financial markets. The Johansen cointegration test revealed a negative but significant relationship between money market interest and the stock market, according to [2]. The study looked at the long-term relationship between the money market, interest rates, and stock market return in Zimbabwe from April 2009 to December 2013. The Johansen cointegration test revealed a negative but significant relationship between both the interest on the financial markets and the stock market according to [2]. The findings of the study indicated a long-run association among the financial markets, interest rates and return on the stock market in Zimbabwe from 2009 to 2013.

\subsection{Empirical Findings in Ghana}

The interaction between economic determinants and the performance of the stock index has only been explored in a few studies in Ghana. The following study looked at the relationship between Ghana's financial markets and the country's interest rate. Research conducted by[13] indicated in the long run, interest rates provide a more significant effect on stock market capitalization than they do in the immediate term. [14] using monthly data from 2010 to 2013 to analyze the impact of interest rates and liquidity growth on Ghana's stock market returns. There was evidence that the Ghana stock market indexes are heavily influenced by volatility rise, exchange rate, and inflation after they used robust linear regression (MEstimation). The study also indicates a slight positive relationship among the interest rate and the performance of the GSE.[15] When examining the effect of the interest rate on the return on the stock market, it is exaggerated. The study used multiple regression estimates using the Ordinary Least Square Estimator (OLS) as well as the time series technique developed by Box-Jenkins. The results found that interest rates did not have a major impact on stock returns, confirming his hypothesis. The costs of crude on the worldwide market and, therefore, the exchange rate also failed to influence the stock returns. [16] conducted an identical work to find the influence of economic indicators on stock indexes within the Ghanaian economy. The analysis centered on each the end of the day and short-run relation regarding the variables in question. The research tactic was supported by Johansen's variable cointegration take a look at and procedures innovation accounting. The study is unconcealed that in Ghana, there is the presence of an extended run relation regarding the economics 
variables utilized in the study and stock costs in African country. The response of impulse perform and decomposition of the error Variance show that rate of interest and direct investment by foreigners tends to be vital influencers of the movements ascertained within the costs of shares.

The above studies of various literature reviewed revealed that macroeconomic indicators and interest rates have a relationship. According to various analysts, many macroeconomic variables, such as interest rate, inflation rate, exchange rate, money supply, and Gross Domestic Product (GDP), affect stock markets' performance. This study aims to identify a relationship between the interest rate and the current stock of Ghana Stock Exchange Indexes. This study will also use yearly data from the GSE and ER, IR, CPI, and MS to determine a long-term relationship among the indicators selected for this study.

Ghana's security market is presumed to be a semi-strong market; therefore, it is vital to consistently research its performance to provide updated information to help investors decide. According to the various literature reviewed, the linkage between stock performance and interest rate is still debatable.
Whereas some researchers suggested a negative relationship, others established that the two variables have no link. Much research has been conducted on the link between the stock market and the interest rate in developed and emerging stock markets, but few and literature exist regarding underdeveloped economies like Ghana. This has created a literature gap, which has necessitated this research to determine the influence that macroeconomic indicators have on the Ghana Stock Market. In filling the gap, the selected variables will be carefully and critically analyzed to obtain the GSE movement's actual variables.

\section{DATA AND METHODOLOGY} 3.1. Data Source

Interest rate, Consumer Price Index (Inflation), exchange rate, money supply, and the Ghana Stock Exchange composite index are secondary data used in this report. The World Bank Development Indicators provided all of the secondary data, but the GSE composite Index data was gathered from the Ghana Stock Exchange.

\subsection{Model Specification}

\subsubsection{Variables Estimation and Analytical Framework}

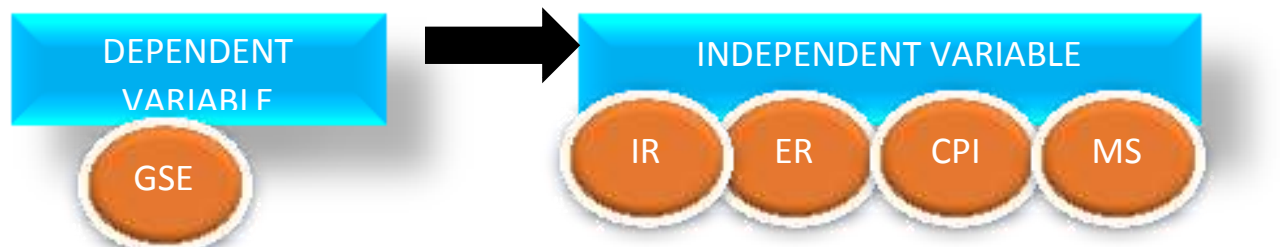

Figure 2. Variables Estimation and Analytical Framework for the study

\subsection{Variables Description and Characteristics}

\subsubsection{Dependent Variables}

This research model's dependent variable is the Composite Index from the Ghana Stock Exchange as the researcher seeks to determine the macro-economic factors that affect its movement. Previously, the GSE Composite Index was called the All-Share Index. .'

\subsubsection{Independent Variables}

For this research, the Government of Ghana's T-bill rate will be used as the prevailing Interest Rate (IR). The financial market comprises both the money and capital market. In the money market, short-term assets such as T-bill, Commercial paper, among others, are traded, and in the capital market, long-term assets such as shares, bonds, and derivatives instruments are traded. This study uses the Exchange Rate (ER) for Ghana cedi (GHS) to the United States Dollar (\$). The choice of the US dollar is that the currency is considered a major one for international business transactions in Ghana, and it also fluctuates more often in the country. Consumer Price Index (CPI) is used as a substitute for inflation in the context of this study. Inflation could affect returns on shares either positively or negatively depending on the country's inflationary status due to the aggregate supply in the economy falling short of aggregate demand.

The narrowly defined money (M1) is used for the study since it is considered the most readily available money supply category for business transactions. This definition includes all physical cash like notes and coins and customer deposits, and other liquid assets held by the Bank of Ghana. Money Supply(MS) and stock prices are generally assumed to have a positive relationship.

\subsubsection{Variables Description and Characteristics}

The time-series data with 20 yearly observations for the four selected microeconomic indicators and the Composite Index of the Ghana Stock Exchange is 
analyzed rigorously utilizing the Augmented DickeyFuller (ADF) test method to analyzed stationarity of the data. This paper resulted in the Granger causality model to ascertain the response variable's causal link and the explanatory variables. The Johansen Co- integration test is also used to establish the long-term linkage between GSE and the four chosen independent variables. This analysis was aided by E-view software. The analytical model used for this study:

$$
\ln G S E_{t}=\alpha_{0}+\alpha_{1} \ln E R_{t}+\alpha_{2} \operatorname{lnIR}{ }_{t}+\alpha_{3} \operatorname{InCPI}_{t}+\alpha_{4} \ln M S_{t}+\mu_{t}
$$

Where

\section{Dependent Variable}

GSE - stock returns from the Ghana Stock Exchange, which is the dependent variable for the studies.

\section{Independent Variable}

The control Variables or the independent variable included in the study are;
ER- Exchange rate precisely the cedi to United State Dollars for the selected period

IR - Interest rate in the research

CPI- Consumer Price Index used as a proxy for inflation

MS- Broad Money supply

Where all the variables are explained above $\alpha_{\mathrm{t}}$ are the elasticities given the log-log specification, and $\mu_{t}$ denotes the error term.

\section{RESULTS AND ANALYSIS 4.1 Descriptive Statistics}

Table 1: Descriptive Statistics of the Variables

\begin{tabular}{lllllll}
\hline Variable & Mean & $\begin{array}{l}\text { Standard } \\
\text { Deviation }\end{array}$ & $\begin{array}{l}\text { Maximum } \\
\text { Value }\end{array}$ & $\begin{array}{l}\text { Minimum } \\
\text { Value }\end{array}$ & Skewness & Kurtosis \\
\hline GSE & 36.88 & 37.20 & 154.67 & 3.10 & 1.78 & 6.07 \\
ER & 1.97 & 1.41 & 4.58 & 0.544 & 0.83 & 2.07 \\
IR & 18.87 & 4.93 & 27.00 & 12.50 & 0.42 & 1.86 \\
CPI & 14.70 & 6.77 & 32.93 & 6.700 & 1.25 & 4.06 \\
MS & 1874.77 & 20928.98 & 62657.63 & 530.49 & 1.015 & 2.62 \\
\hline
\end{tabular}

GSE had a standard deviation of approximately 37.2 points; this indicates a more significant mean variation. The minimum and maximum values of the GSE were approximately 3.10 and 154.67 points, respectively. Also, the interest rate's standard deviation is approximately GH $\not 1$, meaning a lower spread from the mean. The interest rate has minimum and maximum values of $\mathrm{GH} \phi 0.05$ and approximately $\mathrm{GH} \phi 4.5$, respectively. From the descriptive analysis table, interest rate (IR) has a mean of approximately $19 \%$. The meaning is that the rate investors on the money market received on their investments on average was approximately $19 \%$. Again, CPI has approximately $6.7 \%$ standard deviation meaning less spread from the mean but more significant variability in yearly CPI figures. Also, the minimum and maximum values of the CPI are approximately $6.7 \%$ and $32.93 \%$, respectively.

The money supply has a standard deviation of approximately GH $\notin 20928.98$ million, meaning more excellent dispersion from the mean. The minimum and maximum money supply values were approximately GHф 530.4900 million and GHф62657.63 million, respectively. Meanwhile, all the kurtosis values of the variables are more significant than zero (0). The dataset has a leptokurtic distribution (fat tails), meaning that the shape of the distribution of the research variables is mostly higher than the shape of a normal distribution (tin tails). The result from the kurtosis implies that the variables selected have effect on the performance of financial market indexes. 


\subsection{Unit Root Test}

Table 2: Unit Root Test (ADF)

\begin{tabular}{lccl}
\hline \multicolumn{2}{l}{ Augmented Dickey-Fuller Test } & & \\
\hline Variable & Test Statistics & Critical value (5\%) & Conclusion \\
& & & \\
\hline Log Level & & & \\
\hline InGSE & -3.004 & -3.831 & Non-Stationary \\
InER & -0.034 & -3.041 & Non-Stationary \\
InIR & -3.481 & -3.857 & Non-Stationary \\
InCPI & -2.796 & -3.030 & Non-Stationary \\
InMS & -2.675 & -3.691 & Non-Stationary \\
\hline & & First log difference & \\
\hline$\Delta$ InGSECI & -7.627 & -3.920 & Stationary \\
$\Delta$ InER & -3.040 & -2.239 & Stationary \\
$\Delta$ InIR & -3.420 & -3.051 & Stationary \\
$\Delta$ InCPI & 9.014 & -3.040 & Stationary \\
$\Delta$ InMS & -3.873 & -3.099 & Stationary
\end{tabular}

From Table 2, it can be concluded that no variables were stationary at the log level as the P-values or the critical values are more significant than the test statics at the level of . In order to do proper analysis, it is essential to make these variables stationary. At first log difference, the null hypothesis of all the variables was rejected and accepted the variables' alternate hypothesis because the variables had a test statistic, which was more negative than the critical values. Generally, all the variables for the study were stationary at order one I(1).

\subsection{Johansen Co-integration Test (Long Run Interaction)}

A cointegration test was conducted in this study to analyze the long-run relationship between the dependent and the independent variables.

Table 3: Co-integration Test (Trace \& Max Eigenvalue)

\begin{tabular}{lllll}
\hline $\begin{array}{l}\text { Hypothesized } \\
\text { No. of CE(s) }\end{array}$ & Eigenvalue & Trace Statistics & $\begin{array}{l}\mathbf{0 . 0 5} \\
\text { Critical Value }\end{array}$ & Probability \\
\hline 0 & & & 69.8188 & 0.0000 \\
1 & 0.9543 & 132.8584 & 47.8561 & 0.0000 \\
2 & 0.8885 & 77.28464 & 29.7970 & 0.0049 \\
3 & 0.7552 & 37.7984 & 15.4947 & 0.1361 \\
4 & 0.4648 & 12.4608 & 3.8414 & 0.2715 \\
\hline
\end{tabular}

The outcome or outcomes of the Trace statistics are shown in Table 3 . The Trace statistics of 132.85 were higher than the substantial value of 69.81 , and it has a chance of 0.000 , or less than $5 \%$, according to the findings. The implications or interpretation of these findings suggest that the variables are cointegrated, implying that the variables chosen for this study have a long-run relationship. 
Table 4 show the results of Max-Eigen statistics

\begin{tabular}{lllll}
\hline & \multicolumn{3}{c}{ Cointegration Rank Test (Maximum Eigenvalue) } \\
\hline $\begin{array}{l}\text { Hypothesized } \\
\text { No. of CE(s) }\end{array}$ & Max-Eigenvalue Statistics & Eigenvalue Statistics & $\mathbf{0 . 0 5}$ & Probability \\
& & & Critical Value & \\
\hline 0 & 0.9543 & 55.5738 & 33.8768 & 0.0000 \\
1 & 0.8884 & 39.4862 & 27.5843 & 0.0000 \\
2 & 0.7552 & 25.3375 & 21.1316 & 0.0120 \\
3 & 0.4647 & 11.2519 & 14.2646 & 0.1420 \\
4 & 0.0649 & 1.2089 & 3.84146 & 0.2715 \\
\hline
\end{tabular}

The Max-Eigen statistics of 55.57 in table 4 is higher than the critical value of 33.87 , indicating that the variables are cointegrated. This also implies that the dependent and independent variables used in this analysis have a long-term relationship.

$$
\operatorname{InGSE}=370.552-436.71 \ln E R-14.6288 \ln I R+18.94 \ln C P I+0.0247 \ln M S
$$

The exchange rate (ER) coefficient has a negative 436.717 , which is a highly significant figure. The country's exchange rate movement could explain holding all other factors constant, 436.7 of the vibration in Ghana stock market indexes. The negative sign also depicts that as the exchange rate decreases, GSE is expected to increase. The negative impact of exchange rate on the GSE agrees with [17] they found through independent researches that exchange rate was inversely related to sharing prices in China and BRICS countries, respectively.

This result is consistent with [18], who discovered a inverse relationship between stock market returns and interest rates in his research. Furthermore, research by [10] verified the inverse relationship between GSE and interest rate. There is an inverse correlation of about $-14.63 \%$ regarding interest rate (IR). 0.01463 of the GSE's movement is explained by shifts in the economy's interest rate movement, assuming all other factors remain stable. The negative sign also means that a $1 \%$ rise in interest rates would cause the GSE composite indexes to fall 14.63 percent if all other factors remain constant.

The Consumer Price Index (CPI) coefficient value is positive at $19 \%$, indicating that, all others being equal, consumer price indexes explain $18.95 \%$ of the GSE movement difference. The positive sign also represents a change in the same direction, which means that if all other variables remain stable, a $1 \%$ increase in inflation will cause stock price indices to rise by 18.95 points. This statement is in line with the results [15] and [19], which found a positive relationship among inflation and financial market in Ghana.

The 0.0247 coefficient of money supply (MS)

\subsection{Cointegration equation}

The multiple regression adopted for this research is stated as:

indicates that the money supply movement will explain $2 \%$ of the difference in GSECI when all other variables are kept constant. The positive sign also explains a positive relationship between the money supply and the GSE composite index, meaning that a $1 \%$ rise in the money supply would result in a 0.0247 -point increase in GSE indexes. Money Supply (MS) and GSE agree with the studies conducted by [20]. Various researchers argued that when the money supply in a country increases, demand for money increases and signals an increase in economic activities, thereby shooting up stocks' prices. The long-run effect is that there will be much money in circulation to decide to make investment decisions. These people can end up investing in the stock market or invest in any other business.

\subsection{Granger Causality Test}

Events in the past can cause events to happen today. That to say that there may be situations when something causes another thing to happen later. This calls for the need for the Granger causality test to be applied when researching time series data. After defining the long-term relationship between stock market indices and selected macro-economic indicators, this was imperative to consider or examine how these variables interact. The Granger causality test was being used once again to see if the predictor variables are effective for predicting the dependent variable. To use the probability of testing this hypothesis, if the significance level exceeds the threshold of $5 \%$, the null hypothesis is accepted, signifying no causal relationships among factors selected for this study. 
Table 5: Granger Causality Test

\begin{tabular}{lcc}
\hline \multicolumn{1}{c}{ Null Hypothesis } & Probability & Accepted/Rejected \\
\hline ER does not Granger Cause GSE & 0.2978 & Accepted \\
CPI does not Granger Cause GSE & 0.6332 & Accepted \\
IR does not Granger Cause GSE & 0.3327 & Accepted \\
MS does not Granger Cause GSE & 0.2852 & Accepted \\
CPI does not Granger Cause ER & 0.9717 & Accepted \\
IR does not Granger Cause ER & 0.8729 & Accepted \\
MS does not Granger Cause ER & 0.6416 & Accepted \\
IR does not Granger Cause CPI & 0.0492 & Rejected \\
CPI does not Granger Cause MS & 0.8480 & Accepted \\
MS does not Granger Cause CPI & 0.4520 & Accepted \\
GSE does not Granger Cause ER & 0.8792 & Accepted \\
IR does not Granger Cause MS & 0.6386 & Accepted \\
CPI does not Granger Cause IR & 0.9659 & Accepted \\
GSE does not Granger Cause IR & 0.0376 & Accepted \\
GSE does not Granger Cause CPI & 0.5983 & Accepted \\
GSE does not Granger Cause MS & 0.8553 & Accepted \\
ER does not Granger Cause MS & 0.0048 & Rejected \\
ER does not Granger Cause IR & 0.9659 & Accepted \\
MS does not Granger Cause IR & 0.9967. & Accepted \\
\hline
\end{tabular}

From Table 5 it can be observed that most of the macroeconomic indicators Granger cause each other. It can that identified that ER, IR, CPI, and MS do not Granger cause the GSE. Also, not all the independent variables have causal relationships with one another. The analysis indicates a bi-directional non-causation of the study variables. In summary, as the purpose of this study to establish the causality among the chosen variables, it has emerged that few of the independent factors (ER, IR, CPI, and MS) Granger cause the dependent variable (GSE). [21] attributed the noncausality of the chosen macroeconomic variables and the Bangladesh stock return to the inefficient Bangladesh Stock Market, and the same can be said for the Ghana Stock Exchange Composite Indexes, which agrees with the results of this study.

\section{FINDINGS AND CONCLUSION}

This paper's ultimate goal was to use Johansen's Multivariate Cointegration Analysis to analyze the effect of microeconomic indicators on GSE composite indexes. The data for this study was compiled over 20 years, from 2000 to 2019. Inflation, money supply, the Government of treasury bill as a predictor for interest rate, currency exchange rate, specifically the Ghana Cedi to US Dollar exchange rate, and Composite Share Indexes of the Ghana Stock Exchange was used microeconomic indicators for this study.

The paper reviewed that, in the short term, consumer stock indexes are significantly influenced by consumer price indexes and money supply. The positive relation between these variables tells us that investors will be compensated for the intermittent increase in inflation in the short-term coefficient value of money supply (MS) indicates that holding all other 
factors constant, the movement in money supply could explain $2.47 \%$ of the variation in GSECI. The exchange rate (ER) coefficient has a negative 436.717 , which is a highly significant figure. The movement in the country's exchange rate could explain holding all other factors constant, 436.7 of the vibration in Ghana stock market indexes

Interest rate have a large impact on stock market indices; with a coefficient of 14.63 , a $1 \%$ increase in interest rates causes a $14.63 \%$ drop in stock market indexes. The negative relation between these two variables is expected for the Ghanaian economy. This is because, in Ghana, an interest rate is seen as an alternative investment opportunity. An increase in interest rates would force investors to spend less in the stock market in a given economic situation because the opportunity cost of investing in the stock market is much lower than investing in the stock market. Consequently, investors will channel their resources into highly risky assets like interest rate rises. In the long-term, given the data set, the Ghana Stock Exchange Composite indexes (GSE) have a significant relation with three selected indicators. Thus, money supply (MS), consumer price indexes(CPI), and interest rate (IR) with a significant level of $0.002,0.001$, 0.0024 , respectively. These P-values are below the critical value of $5 \%$. It is also clear that the exchange rate seems to have no substantial long-term relationship with GSE composite indices.

Based on this study's findings, the following suggestion or recommendations were proposed for better operation on the Ghana stock exchange.

i. Listed firms on the Ghana Stock Exchange: Once investors know that listed firms on the GSE have a better performance combined with the fact that share returns increase as inflation rises, shares can be preferred when investors need to hedge against inflation risk. Firms listed on the Ghana Stock Exchange should strive to make their stock appealing to investors, as firm stocks appear to be a good hedge for investors over the long term.

ii. Ghana Stock Exchange Commission (SEC): This finding will be shared with the Ghana Stock Exchange authorities, who might be informed that Ghanaian stocks cannot be used as a hedging tool against inflation. Since the coefficient is positive, a higher rate of return on socks is required with a higher inflationary rate.

iii. Policy level: This research will help policymakers prepare for the future, like designing and implementing effective fiscal and monetary policies to maintain the financial market. The development of a regulatory regime for listed companies and the Ghana stock exchange and financial sector reform will be crucial.

iv. Investment Decision: Investors may use this research to predict or predict the profitability of the stock market and make critical decisions as to whether or not to spend in a particular financial market. This is because the impact of microeconomic factors on the economies of developed and developing countries should not be ignored.

v. Addition to literature: This study would add to the body of knowledge on how the stock market is affected by economic variables. No recent studies have shown a long relationship among interest rate and the outcome of the developing stock market, such as Ghana Stock Exchange.

Acknowledgments

No funding to declare

\section{REFERENCES}

1. J. Aduda, J. M. Masila, and E. N. Onsongo, "The Determinants of Stock Market Development: The Case for the 【Nairobi】 Stock Exchange," Int. J. Humanit. Soc. Sci., vol. 2, no. 9, pp. 214-230, 2012.

2. T. Kganyago and V. Gumbo, "An empirical study of the relationship between money market interest rates and stock market performance: Evidence from zimbabwe (2009-2013)," Int. J. Econ. Financ. Issues, 2015.

3. E. Benson, I. I. U. G. Chris-ejiogu, I. I. I. Simon, and T. Utsev, "Analysis of the Applicability of Micro-Economic Variables on Stock Market Performance," vol. 6, no. 3, 2019.

4. M. A. Ruhomaun, M. Saeedi, and N. Nagavhi, "The Effects of Selected Macro \& Micro Economic Variables on Firm Performance for Listed Firms in the "Industrial Products "Sector in Malaysia," no. 5, pp. 95-101, 2019.

5. D. S. Oprea, "The Fisher effect: Evidence from the Romanian Stock Market," Int. J. Acad. Res. Bus. Soc. Sci., vol. 4, no. 5, p. 637, 2014.

6. P. Afordofe and others, "The impact of selected macroeconomic variables on resource equity prices on the Johannesburg Stock Exchange," University of Pretoria, 2012.

7. C. Geetha, R. Mohidin, V. V. Chandran, and V. Chong, "The relationship between inflation and stock market: Evidence from Malaysia, United States, and China," Int. J. Econ. Manag. Sci., vol. 1, no. 2, pp. 1-16, 2011.

8. S. M. Hosseini, Z. Ahmad, and Y. W. Lai, "The role of macroeconomic variables on stock market index in China and India," Int. J. Econ. Financ., vol. 3, no. 6, pp. 233-243, 2011.

9. F. Jareño, "Applied Econometrics and International Development Vol. 19-1 (2019)," vol. 
19, 2019.

10. M. D. Alam, G. Uddin, and others, "Relationship between interest rate and stock price: empirical evidence from developed and developing countries," Int. J. Bus. Manag. (ISSN 1833-3850), vol. 4, no. 3, pp. 43-51, 2009.

11. N. Musawa and C. Mwaanga, "The Impact of Commodity Prices, Interest Rate and Exchange Rate on Stock Market Performance: Evidence from Zambia," J. Financ. Risk Manag., vol. 06, no. 03, pp. 300-313, 2017, doi: 10.4236/jfrm.2017.63022.

12. K. Shula, "The Impact of GDP, Inflation, Interest and Exchange rates GDP on the Stock Market in Zambia," no. March 2017, doi: 10.13140/RG.2.2.11457.56160.

13. L. A. Asamoah, J. A. Agana, and D. Sakyi, "Does interest rate matter to the Ghanaian stock market? " Int. J. Manag. Pract., vol. 9, no. 2, pp. 159-172, 2016, doi: 10.1504/IJMP.2016.076744.

14. M. K. Boachie, I. Osei Mensah, A. Opoku Frimpong, and M. Ruzima, "Interest rate, liquidity and stock market performance in Ghana," Int. J. Account. Econ. Stud., vol. 4, no. 1, p. 46, 2016, doi: 10.14419/ijaes.v4i1.5990.

15. L. Menike, "The Effect of Macroeconomic Variables on Stock Market Returns in Ghana (2000-2013)," Sabaragamuwa Univ. J., vol. 6, no. $1,2013$.

16. P. Guan, D. S. Huang, and B. Sen Zhou, "Forecasting model for the incidence of hepatitis $A$ based on artificial neural network," World J. Gastroenterol., vol. 10, no. 24, pp. 3579-3582, 2004, doi: 10.3748/wjg.v10.i24.3579.

17. V. Tripathi and V. Bhandari, "Socially responsible stocks: a boon for investors in India," J. Adv. Manag. Res., vol. 12, no. 2, pp. 209-225, 2015, doi: 10.1108/JAMR-03-2014-0021.

18. J. H. Eita and A. C. Jordaan, "A causality analysis between financial development and economic growth for Botswana," African Financ. J., vol. 12, no. 1, pp. 72-89, 2010.

19. A. M. Adam and G. Tweneboah, "Do Macroeconomic Variables Play Any Role in the Stock Market Movement in Ghana?," SSRN Electron. J., no. 9368, 2011, doi: 10.2139/ssrn.1152970.

20. M. A. B. M. T. Thaker, "Munich Personal RePEc Archive Effects of Macroeconomic Variables on Stock Prices in Malaysia: An Approach of Error Correction Model PRICES IN MALAYSIA : AN APPROACH OF ERROR," no. 20970, 2010.

21. E. K. Chowdhury, "Measuring the Effect of Macroeconomic Variables on the Stock Market Return: Evidence From Chittagong," Assumption. Univ. Interdiscip. Res., vol. 2, no. 2, pp. 1-10, 2017. 